\title{
Analysis of the Implementation of the Quarantine Law Indonesia's Health During the Covid Pandemic 19
}

\author{
Megawati Barthos \\ Borobudur University \\ \{megawati_barthos@borobudur.ac.id\}
}

\begin{abstract}
The COVID 19 pandemic has changed the habits that exist in society. The Government of the Republic of Indonesia uses Law Number 2 of 2002, Article 84, and Article 93 of Law Number 6 of 2018 concerning Health Quarantine to regulate society during the Covid 19 pandemic. However, how is the implementation in society? By using a qualitative approach and descriptive analysis method, it was found that many violations occurred in the community. Crowd offense was a widespread problem. Recommendations that can be done so that violations can be mitigated are socialization through community structures and using local wisdom as a bridge to enforce the health quarantine law.
\end{abstract}

Keywords: Health Quarantine; Law; Covid-19

\section{Preliminary}

The covid pandemic has changed the face of the world in general. There is nothing that is not affected by the Corona Virus. A virus that can spread quickly makes governments around the world try to survive in various ways to suppress its spread. The spread is very fast and widespread resulting in a short time after it first spread in China, the Covid-19 pandemic has plagued 212 countries in the world. In Indonesia itself, the Covid-19 pandemic has plagued all provinces.[1]

It is undeniable that the emergence of the Corona Virus Disease 2019 (Covid-19) pandemic has indeed caused a lot of controversies. However, along with various discourses about Covid-19, the World Health Organization (WHO) has finally designated the spread of COVID-19 as a Global Pandemic. In term, pandemic refers to a disease that spreads to many people in several countries at the same time. In fact, the spread of the coronavirus itself is increasing significantly and sustainably globally. [2]

The very fast and widespread spread of the Covid-19 pandemic requires the Government to take quick and precise steps in handling it to overcome and suppress the spread of the Covid-19 pandemic. The issuance of legal products at the central level, both in the form of regeling and in the form of beschikking, is very urgent and awaited by each region because the legal products issued will be the basis for the formation of legal products at the regional level related to the handling of the Covid-19 Pandemic.

The Indonesian government has also responded to this condition by issuing Presidential Decree No.11 of 2020 on March 31, 2020, concerning the Determination of Public Health 
Emergencies for Corona Virus Disease 2019 (Covid-19). This is motivated by the extraordinary spread of Corona Virus Disease 2019 (COVID-19), marked by the number of cases and/or the number of deaths that have increased and spread across regions and countries and have an impact on political, economic, social, cultural aspects. defense and security, as well as the welfare of the people in Indonesia, so that by referring to Law Number 6 of 2018 concerning Health Quarantine, Covid-19 is seen as a type of disease that causes a Public Health Emergency.

The inclusion of Republic of Indonesia Law Number 6 of 2018 concerning Health Quarantine has led to a heated conversation in the public regarding the term 'lockdown' and large-scale social restrictions (PSBB). Article 1 number 10 of Law of the Republic of Indonesia Number 6 of 2018 states, Regional Quarantine is a restriction on the population in an area including the Entrance Area and its contents suspected of being infected with a disease and/or contamination in such a way as to prevent the possibility of spreading disease or contamination.[3]

This is what became known as the 'lockdown'. Meanwhile, Large-Scale Social Restrictions (PSBB) based on Article 1 point 11 are restrictions on certain activities of residents in an area suspected of being infected with a disease and/or contamination in such a way as to prevent the possibility of spreading disease or contamination. However, despite differences of opinion regarding government policies in implementing lockdown or PSBB, in the end, the government chose the PSBB policy with the issuance of Government Regulation Number 21 of 2020 concerning Large-Scale Social Restrictions (PSBB). This paper will analyze the implementation of Law Number 2 of 2002, Article 84, and Article 93 of Law Number 6 of 2018 concerning Health Quarantine, which are the regulations used to regulate the community during the Covid 19 pandemic.

\section{Research Method}

This research uses a normative juridical approach, which is legal research that is only based on secondary data in the form of laws and other libraries related to the recognition and religious freedom of indigenous peoples, which is analyzed by legal reasoning including interpretation activities, systematization, and evaluation of legal rules, which refers to positivity (certainty), coherence and justice.[4]

\section{Results and Discussion}

The main topic across the country in recent months has been the coronavirus. The Corona, which is attacking people throughout the country indiscriminately according to WHO, is the Novel Coronavirus (2019-nCov) which initially began to spread in the city of Wuhan, China, which was first thought to have originated from a wild animal market and this virus was found in animals that could be transmitted from animal to human (zoonosis), and it was later known that it could also be transmitted from human to human. Which way of transmitting the Covid19 virus can be from fluids when sneezing or coughing, air, direct contact, animals and close even with patients who have been infected first. This virus takes the shortest incubation time of two to three days and the longest.

In dealing with the Covid-19 pandemic, the central government issued various legal instruments in the form of Ministerial Regulations, Presidential Decrees, and the making of 
Laws. It can be said that the government is doing the right thing because legal instruments are a firm and effective practical solution in solving various problems including the Covid-19 problem. This needs to be further appreciated when the government takes mitigation, minimization, and prevention efforts at the right time. Unfortunately, reality doesn't say that. Based on the provisions of the applicable laws, the Covid 19 Pandemic is included in force majeure. According to Munir Fuady's explanation that force majeure, namely [5] :

a. Force majeure is subjective. The Covid 19 outbreak can be categorized as a reason for subjective force majeure, in which this situation is compulsive so that the achievements that arise from an agreement cannot be fulfilled due to matters related to the actions or abilities of the debtor itself, without any elements. error and without an element of good faith from the debtor concerned. In another sense, for example, someone is tested positive for the Covid 19 Virus or someone is being monitored, then this is considered the debtor as unable to excel at that time.

b. The Covid 19 outbreak is categorized as a reason for relative force majeure, which is a compelling situation in which the achievement is not possible under normal circumstances, even though it may still be done abnormally. For example, with the prohibition of going home, PSBB (Large-Scale Social Restrictions), social distancing has an impact on not fulfilling the implementation of the agreement. For example, with the prohibition of not selling, the mass termination of employment results in a person not being able to fulfill credit payments, a normal sale and purchase agreement. This then resulted in the fulfillment of the agreement having to be postponed until an undetermined time. This risk management must be planned by the parties after the enactment of government policies related to the Covid 19 outbreak.

c. The Covid 19 outbreak is categorized as a reason for temporary force majeure, which is a compelling situation in which the achievements issued from an agreement are not possible for a while. This means that some scientists predict that the Corona Outbreak will end at the end of the year. It was then that the Covid 19 outbreak was categorized as a reason for temporary force majeure, not permanence.

d. The state of the Covid 19 outbreak as a form of force majeure for agreements in general. This is due to the existence of government policies. The agreements referred to are not only in certain agreements but agreements, in general, are included in this group. The agreement in question is an agreement that has been agreed by the parties, binds the parties, and does not violate public order, statutory regulations, or nosiness, including this agreement in general. Agreements, in general, include sale and purchase agreements, lease agreements, credit agreements, and so on.

e. The Covid 19 outbreak is also a force majeure due to impracticality. The impracticality of carrying out the achievement, an event occurred which was also without mistake from the parties in the agreement, the event occurred in such a way, wherewith the event the parties theoretically, is still possible to carry out the achievement of the agreement, but practically it occurs in such a way so that even if carried out this achievement, will require a very large sacrifice and is not worth it in terms of cost, time or other sacrifices. Therefore, the implementation of such agreements is considered by law to be "impractical" (impracticable) or "difficult to carry out" (hardship). So the point is that the Covid 19 outbreak has an impact on the impracticality of implementing the agreement. If the agreement is to be carried out there will be enormous sacrifices, both in terms of costs, time, and health of each party itself.

The Indonesian government continues to strive to stop the spread of the coronavirus by issuing several policies, including: 
a. Government Regulation (PP) No.21/2020 concerning Large-Scale Social Restrictions.

b. Presidential Decree (Kepres) No.11 / 2020 concerning Determination of Public Health Emergencies

c. Regulation in Lieu of Law (Perppu) No.1 / 2020 concerning State Financial Policy and Financial System Stability for Handling the COVID-19 Pandemic and in the Context of Threats that Endanger the National Economy or Financial System Stability.

The inclusion of Republic of Indonesia Law Number 6 of 2018 concerning Health Quarantine has led to a heated conversation in the public regarding the term 'lockdown' and large-scale social restrictions (PSBB). Article 1 number 10 of the Republic of Indonesia Law Number 6 of 2018 states, Territorial Quarantine is a restriction on the population in an area including the Entrance Area and its contents suspected of being infected with a disease and/or contamination in such a way as to prevent the possibility of spreading disease or contamination. This is what became known as the 'lockdown'. Meanwhile, Large-Scale Social Restrictions (PSBB) based on Article 1 point 11 are restrictions on certain activities of residents in an area suspected of being infected with a disease and/or contamination in such a way as to prevent the possibility of spreading disease or contamination. However, despite variations of opinion regarding government policies in implementing lockdown or PSBB, in the end, the government chose the PSBB policy with the issuance of Government Regulation Number 21 of 2020 concerning Large-Scale Social Restrictions (PSBB).

In line with the demands for the development of the situation and conditions that are frequently urgent and the handling of the spread of Corona Virus Disease 2019 (Covid-19) which cannot be handled under 'normal' conditions, in the end, President Joko Widodo on April 13, 2020, issued Presidential Decree No. 2020 concerning the Determination of NonNatural Disaster for the Spread of Corona Virus Disease 2019 (COVID-19) as a National Disaster. In this beschikking, the President referred to two laws as the basis for their implementation, namely Republic of Indonesia Law Number 4 of 1984 concerning Infectious Disease Outbreaks and Law of the Republic of Indonesia Number 24 of 2007 concerning Disaster Management.[6]

Therefore, the issuance of Presidential Decree Number 12 of 2020 dated April 13, 2020, concerning the Determination of the Non-Natural Disaster for the Spread of Corona Virus Disease 2019 (COVID-19) as a National Disaster is what furthermore becomes a reference as well as a legal basis for the Provincial / Regency / City Governments to determine Emergency Response Status for Non-Natural Pandemic COVID-19 Disaster, through the Decree of the Regional Head of the Governor / Regent / Mayor in their respective regions.

There are several regulations relating to the implementation of the PSBB. Among others is PP. 21/2020 concerning Large-Scale Social Restrictions in the Context of Accelerating the Handling of Corona Virus Disease 2019 (COVID-19), Regulation of the Minister of Health (Permenkes) Number 9 of 2020 concerning Guidelines for Large-Scale Social Restrictions in the Context of Accelerating the Handling of Corona Virus Disease 2019 (COVID-19) ), as well as Government Regulation in Lieu of Law (Perppu) Number 1 of 2020 concerning State Financial Policy and Financial System Stability for Handling the Corona Virus disease 2019 pandemic and/or in the Context of Facing Threats that Endanger the National Economy and/or Financial System Stability. [7]

Various policies appear to be used to combat this virus, sometimes causing confusion or even pros and cons. On the one hand, some efforts will be taken to prevent the spread by removing the prisoners who are still in prison, but on the other hand, some regulations threaten to put in prison cells for people who violate the rules related to preventing this outbreak. [8] 
So it can be seen that this rule is contrary to other legal regulations to prevent the spread of the Covid-19 pandemic. [9]

Law No. 6/2018 on Health Quarantine, in particular Article 93, already regulates the rules for violators of large-scale social restrictions (PSBB), in addition to Article 218 of the Criminal Code. The government then followed up on this by issuing Government Regulation (PP) Number 21 of 2020 concerning Large-Scale Social Restrictions (PSBB). Therefore, when the Government Regulation has been officially issued, the police, as mandated by the President, will take firm action to enforce the law for violators. This means that prevention of the Covid-19 pandemic outbreak must be done by providing criminal sanctions for citizens who commit violations.[10]

Through the Chief of Police Declaration No. Mak / 2 / III / 2020 regarding Compliance with Government Policies in Handling the Spread of the Corona Virus, then the police took action to secure the public who did not heed the PSBB appeal, although later most of them were released again. However, of course, if this assertiveness is upheld, many members of the community who violate become prisoners, who then legally have to be tried and imprisoned.[8]

\section{Conclusion}

Based on the discussion above, it can be concluded that the Legal Policy Against the Handling of the Covid-19 Pandemic in Indonesia has not been properly implemented as mandated in the laws and regulations, because there are still many people who violate the PSBB activities. Even though it is clear that there are criminal sanctions that can be imposed on those who commit violations. Under such conditions, the Central and Local Governments should ensure the disclosure of public information in real terms to be able to find out the chain of the spread of the virus and must be able to guarantee and ensure that especially the middle and lower classes can fulfill their needs to guarantee the right to life of their people and not be reduced by anything as the people's dignity (according to the mandate of the 1945 Constitution of the Republic of Indonesia) and the need for a public role in terms of protecting, reminding each other, and helping one another.

\section{References}

[1] A. G. Sari, H. L. Sudarmanto, and H. Murty, "The Policy on Regional Quarantine to Anticipate the Spread of Corona Virus in terms of Law No. 6 of 2018 on Health Quarantine," J. Transparency Huk., 2020.

[2] A. M. Nadhira, "Various Terms Related to Corona Virus and COVID-19," www.alodokter.com, 2020.

[3] F. P. Disantara, "State Responsibility during the Covid-19 Pandemic," JCH (Journal of Legal Scholars), vol. 6, no. 1, p. 48, 2020, doi: 10.33760 / jch.v6i1.262.

[4] M. Abdul Kadir, "Law and Legal Research.," Bandung PT. Citra Aditya Bakti., 2015.

[5] M. Fuady, Concept of Civil Law. Jakarta: PT. RajaGrafindo Persada, 2016.

[6] D. Telaumbauna, "A Judicial Review of Determination of Public Health Emergencies Due to Covid-19," J. Educ. Dev., 2020.

[7] P. S. Saraswati, "Legal Policies for Handling the Covid-19 Pandemic in Indonesia," KERTHA WICAKSANA, vol. 14, no. 2, pp. 147-152, Jul. 2020, doi: 10.22225 / kw. 14.2.1923.147-152.

[8] N. R. Yunus, "Covid-19 Policy, Free Prisoners and," IS Bul. Huk. Justice, vol. 4, no. 1, pp. 1-6, 2020. 
[9] A. S. Rahayu, "Indonesian Version of Lockdown," Publ Archives. Ilm. Adm. Bureau. Akad., 2020.

[10] I. P. G. Suyoga, "PRACTICAL USE OF SOCIO-RELIGIOUS SPACE," Dharmasmrti J. Religious and Cultural Sciences., Vol. 20, no. 1, pp. 77-84, 2020. 